\title{
PERJALANAN SI TUA DALAM NOVELET "SEBUAH MIMPI BUAT HARI TUA": SUATU PENELITIAN GERONTOLOGI
}

\section{(The Journey of the Old in the Novelette "Sebuah Mimpi Buat Hari Tua": A Gerontolgy Study)}

\author{
Mohamed Nazreen Shahul Hamid \\ mohamednazreen25@gmail.com
}

\author{
Md. Salleh Yaapar \\ mdsalleh@USM.MY
}

Pusat Pengajian Ilmu Kemanusiaan, Universiti Sains Malaysia.

Published on: 1 June 2018

To cite: Mohamed Nazreen Shahul Hamid and Md. Salleh Yaapar. (2018). Perjalanan Si Tua dalam Novelet "Sebuah Mimpi Buat Hari Tua": Suatu Penelitian Gerontologi. Malay Literature 31(1), 168-181.

\begin{abstract}
Abstrak
Shahnon Ahmad ialah seorang penulis yang diangkat sebagai Sasterawan Negara oleh Kerajaan Malaysia. Pada masa yang sama, beliau seorang intelektual awam yang digemari oleh masyarakat. Buktinya karyanya Shit (1999) yang amat kontroversial. Dalam berkarya beliau tidak kenal kawan atau lawan, tidak gentar mengungkapkan apa-apa sahaja idea dan pendiriannya. Karyanya mulai tahun 60-an banyak sekali mengetengahkan pelbagai isu yang membelenggu rakyat, di desa dan di kota. Namun begitu, sejak sekitar awal 2000-an apabila memasuki usia emas, Shahnon memperlihatkan perubahan yang ketara dalam penulisannya. Beliau jelas kelihatan mula menerapkan penghayatan usia emasnya dalam karyanya. Dalam konteks tersebut, makalah ini bertujuan menganalisis novelet "Sebuah Mimpi Buat Hari Tua" (2003) dengan tumpuan terhadap keperihalan manusia pada usia emas. Karya ini dikaji berpandukan kerangka konseptual kajian gerontologi kritikal oleh Nancy R. Hooyman dan H. Asuman Kiyak. Kajian mendapati novelet "Sebuah Mimpi Buat Hari
\end{abstract}


Tua" memenuhi tiga dimensi dalam kajian gerontologi kritikal iaitu biologi, psikologi dan sosial. Malah, karya ini juga memperlihatkan apa-apa yang dipaparkan oleh pengarang kelihatan selari dengan pandangan para sarjana dalam gerontologi kritikal. Penemuan kajian ini penting kerana hasilnya menegaskan kedudukan novelet "Sebuah Mimpi Buat Hari Tua" sebagai suatu bahan gerentologi sastera.

Kata kunci: usia tua, gerontologi kritikal, dimensi biologi, dimensi psikologi, dimensi sosial, gerontologi sastera

\begin{abstract}
Shahnon Ahmad is a writer who has been elevated as a National Laurate by the Malaysian government. At the same time, he is a public intellectual well-liked by his community. As evidenced by the highly controversial novel Shit (1999), in producing his works he did not consider friends or opponents, and was never afraid in expressing his ideas and conviction. His works starting from the 60s often highlight various issues plaguing the communities in the urban and rural areas. However, since the early 2000s when Shahnon was at the later stage of his life, his writing had undergone an extreme change. He started to incorporate his experience of old age in his works. In this context, this article aims to analyse a novelette titled "Sebuah Mimpi Buat Hari Tua" (2003), with the focus on the human condition at old age. This work is analysed based on the conceptual framework of critical gerontology by Nancy R. Hooyman and H. Asuman Kiyak. This study finds that the novelette "Sebuah Mimpi Buat Hari Tua" fulfils three dimensions of gerontology, namely biological, psychological, and social. In fact, this literary work shows similarities between the author's perspectives and the views of scholars in critical gerontology. The findings of this study are important because they assert the position of "Sebuah Mimpi Buat Hari Tua" as a material for literary gerontology.
\end{abstract}

Keywords: aging, critical gerentology, biological dimension, psychological dimension, social dimension, literary gerontolgy 


\section{PENDAHULUAN}

Secara sedar ataupun tidak, usia seseorang pengarang sebenarnya mempengaruhi penghasilan karya sasteranya. Biasanya pengarang memperlihatkan peningkatan kematangan dalam karyanya mengikut pertambahan usia. Hal ini amat berkaitan dengan pengalaman pengarang itu sendiri yang mengubah atau berubah wawasan dan cita rasanya dari semasa ke semasa. Oleh itu, tidak hairanlah Syrd Qutb (Sugeng Sugiyono, 1993, p. 56) menyatakan bahawa karya kreatif itu adalah ungkapan yang muncul sebagai inspirasi daripada pengalaman dan cita rasa pengarang pada masa tertentu. Oleh itu, karya kreatif sering menampilkan cita rasa pengarang dan ungkapan yang indah, yang mempunyai kekuatan atau daya penarik serta kebolehan untuk menggugah emosi khalayak pembaca.

Perubahan cita rasa pengarang kerap kali terjadi dan hal ini terbayang pada pemilihan tema atau isu yang dikemukakan. Menurut Rahimah (2017, p. 168) perkara ini berlaku kerana pengarang sentiasa berkembang selari dengan perkembangan usianya, perubahan masa dan alam sekitar. Perkembangan kehidupan itu sedikit demi sedikit turut memberi pengaruh pada perwatakan pengarang kerana serentak dengan perkembangan hidupnya itu, pengarang akan melalui pengalaman baharu. Malah, ia mungkin akan mengulangi pengalaman tertentu. Maka, kehidupan pengarang mengalami perubahan demi perubahan. Misalnya, daripada remaja menjadi dewasa dan tua, daripada tidak sempurna beralih kepada lebih sempurna dan lain-lain lagi. Perubahan itu adalah lumrah, dan secara tidak langsung memberi pengaruh yang cukup besar terhadap proses pembentukan perwatakan pengarang, yang kemudiannya memberikan impak kepada dunia karya kreatifnya (Rahimah, 2017, pp. 168-169).

Perkara ini jika diteliti dengan mendalam turut berlaku dalam penghasilan karya sastera oleh Sasterawan Negara Shahnon Ahmad. Beliau sangat dikenali sebagai penulis yang memiliki pemikiran dan falsafah tersendiri serta seorang pengarang yang sensitif dengan apa-apa yang berlaku dalam hidupnya. Pada awal kegiatan penulisannya, Shahnon sebagai intelektual awam (public intellectual) sangat lantang dalam menampilkan persoalan masyarakat melalui isu-isu seperti kemiskinan, pembangunan tidak terkawal, pencemaran, pengaruh modenisasi dan sebagainya. Namun begitu, setelah memasuki usia sekitar 70 tahun, beliau mula memperlihatkan perubahan "nada" dalam karya yang dihasilkan. Sesuai dengan usianya, beliau lebih banyak merenung kehidupan dengan membawa hal-hal berkaitan dengan usia emas, keinsafan, dan kematian. Bagi menjelaskan pernyataan tersebut, 
kajian ini akan memberikan fokus pada novelet "Sebuah Mimpi Buat Hari Tua" (2003) dalam usaha menganalisis perjalanan usia tua menurut kerangka konsep gerontologi. "Sebuah Mimpi Buat Hari Tua" ialah sebuah novelet dalam Lamunan Puitis - Sebuah Trilogi (2003) terbitan Dewan Bahasa dan Pustaka yang memenangi Hadiah Sastera Perdana Malaysia (HSPM) 2002/2003. Novelet ini bertolak daripada kisah keluarga tiga generasi yang akrab. Dalamnya watak "Aku", isterinya Yati dan anak mereka Seha yang tinggal di sebuah flat di Kuala Lumpur, sering teringatkan atuk dan nenek Seha di Kampung Banggul. Bermula dari situ, usia emas telah mula dibincangkan oleh pengarang melalui unsur-unsur naratif yang dibangunkannya dengan indah. Begitulah, karya ini dapat menjadi sumber sastera yang penting untuk kajian dalam bidang gerontologi.

\section{KERANGKA KONSEPTUAL: GERONTOLOGI DAN SASTERA}

Perkataan gerontologi berasal daripada bahasa Yunani yang membawa maksud ilmu mengenai usia lanjut. Menurut Hooyman dan Kiyak dalam buku mereka, Social Gerontology: A Multidisciplinary Perspective (2008), gerontologi atau teorinya berbicara mengenai proses penuaan dalam pelbagai dimensi, termasuklah biologi, psikologi dan sosial. Bidang kajian ini amat penting, khususnya bagi meningkatkan taraf kualiti warga tua dalam sesebuah masyarakat atau negara.

Menurut Hooyman dan Kiyak, proses penuaan biologi merujuk perubahan fizikal yang berlaku yang menurunkan prestasi fungsi sistem organ seperti jantung, hati dan sebagainya. Penyebab utama kepada penuaan biologi ialah kegagalan sel-sel tertentu dalam menghasilkan sel baharu untuk memastikan sistem organ dan fizikal dapat berjalan seperti biasa. Proses penuaan ini juga dapat dilihat melalui pengukuran tahap perubahan dan kemampuan organ seseorang sama ada dalaman atau luaran. Proses penuaan psikologi pula merujuk perubahan yang berlaku pada proses deria dan persepsi, fungsi mental (ingatan, pembelajaran dan kebijaksanaan), kapasiti adaptasi dan personaliti. Semua ini merupakan perubahan yang sukar dielak, justeru memerlukan perhatian yang lebih daripada golongan muda. Dimensi sosial dalam proses penuaan pula merujuk perubahan dalam hubungan dengan keluarga dan rakan serta masyarakat sekeliling. Perubahan ini berlaku dalam dua situasi, iaitu negatif dan positif. Dalam hal ini, keadaan sekeliling akan menentukan situasi yang mana satu yang akan berlaku. 
Umum mengetahui bahawa semua perkara mengenai proses penuaan dalam ketiga-tiga dimensi di atas dapat difahami melalui gerontologi kritikal/ klinikal (critical/clinical gerontology). Namun begitu, harus dinyatakan bahawa karya sastera juga dapat membantu memberikan pencerahan mengenainya. Sesungguhnya, kajian gerontologi yang menggunakan sastera, yakni gerontologi sastera (literary gerontology), bukan sahaja dapat membantu dalam memahami proses penuaan yang berlaku kepada ibu bapa, datuk dan nenek, tetapi juga membantu dalam proses komunikasi antara warga tua dengan orang-orang yang berada di sekeliling mereka. Hal ini termasuk usaha menangani sebarang andaian atau pandangan stereotaip yang wujud terhadap warga tua. Seperti yang dicatat oleh Zeilig (2011, p. 7):

... narrative and literary approaches to age and ageing when allied to perspectives from critical gerontology can furnish scholars with important perspectives for interpreting and re-configuring 'age'.

Demikianlah pentingnya sinergi antara gerontologi kritikal/klinikal (critical/clinical gerontology) dengan gerontologi sastera (literary gerontology).

\section{ANALISIS TEKSTUAL}

Dalam menganalisis perjalanan usia tua dalam novelet "Sebuah Mimpi buat Hari Tua" dari sudut gerontologi, tiga dimensi utama akan diberikan tumpuan, iaitu biologi, psikologi dan sosial seperti mana yang diberi keutamaan oleh Hooyman dan Kiyak.

\section{Dimensi Biologi}

Pada permulaan cerita, pengarang telah menggambarkan tentang permasalahan yang dihadapi oleh kedua-dua ibu bapa watak utama "Aku" dari sudut proses penuaan biologi. Proses ini telah membawa kepada kurangnya kekuatan daya fizikal dan organ dalaman. Keadaan ini dapat diteliti ketika watak "Aku" yang bimbang sekiranya kedua-dua ibu bapanya menaiki bas datang ke Kuala Lumpur: 
Bapa sudah tua. Emak pun begitu juga. Tentu sulit untuk mereka turun naik bas. Lagi pun bapa dan emak biasanya kerap sangat kencing. Tentu susah sangat-sangat apabila menaiki bas jauh-jauh.

(Shahnon, 2003, p. 3)

Petikan di atas menggambarkan kedua-dua ibu bapa watak "aku" mempunyai masalah dalam sistem urinari, dan keadaan ini sememangnya dihadapi oleh golongan yang berusia lanjut. Dalam gerontologi kritikal perkara ini diperkatakan oleh Hooyman dan Kiyak (2008, p. 87) adalah seperti yang berikut:

... bladder function also deteriorates with age. The capacity of the bladder may be reduced by as much as 50 percent in some older persons...The latter condition may be more a function of central nervous system dysfunction than changes in the bladder. As a result, urinary incontinence is common in older adults.

Sistem urinari merupakan sistem organ dalam tubuh badan yang berfungsi untuk menapis darah daripada bahan toksik dan menghasilkan bahan kumuh, iaitu air kencing. Sistem ini terdiri daripada sepasang buang pinggang, sepasang salur ureter, pundi kencing dan salur uretra. Apabila memasuki usia lanjut, fungsi ini akan berkurang sebanyak lima puluh peratus terutamanya pada bahagian pundi kencing. Akibatnya, masalah kerap kencing akan berlaku. Selain itu, masalah sistem urinari ini bukan sahaja berlaku kepada golongan wanita, yang disebabkan kerosakan dasar pelvis ketika bersalin atau kerosakan sistem saraf pada bahagian pundi kencing. Golongan lelaki juga mengalami masalah sistem urinari akibat kehilangan fungsi sphincter urethrae, iaitu otot yang mengukuhkan uretra. Keadaan ini disampaikan oleh pengarang pada permulaan cerita yang mencatatkan bahawa kedua-dua ibu bapanya mempunyai masalah kerap kencing. Hal ini memperlihatkan bahawa proses penuaan biologi digarap oleh Shahnon, yang pada ketika itu sudah pun berusia 70 tahun.

Selain perubahan organ dalaman yang berlaku kerana proses penuaan biologi, Shahnon juga telah menggambarkan keadaan perubahan fizikal yang berlaku kepada datuk dan nenek watak utama. Situasi ini dapat dilihat melalui keadaan nenek yang diceritakan pengarang semasa pertemuan dengan cucunya Seha: 
... Seha terus saja pusing ke belakang, lari berpatah balik dan panjat tangga jemuran dan terus kapuk neneknya kuat-kuat sampai terketar orang tua itu. Hidung Seha yang mongel itu tertekan jauh ke dalam lopak lipatan dan kedutan pipi neneknya sehingga daging pipi nenek yang bergelember itu terasak sehingga tertampan hujung dagu.

(Shahnon, 2003, p. 17)

Perubahan fizikal, iaitu kedutan pada kulit wajah yang berlaku pada nenek telah menampakkan perubahan pada dirinya ketika menempuh hari tua. Kedutan pada kulit wajah ialah sesuatu yang pasti berlaku kepada semua yang mengalami proses penuaan. Kart dan Kinney (2001, pp. 74-75) mengungkapnya seperti berikut:

Certainly the most obvious age-associated skin change is wrinkling, which begins during one's twenties and continues throughout life. Wrinkling is influenced by several factors. The human face, because of its musculature, is capable of tremendous movement and expression of emotions... The lines that begins to form in areas of greatest movement proliferate and become deeper as the year pass. By the age of 40, most people bear the typical line of their expressions.

Proses kedutan yang berlaku kepada nenek dalam cerita ini, terjadi atas beberapa faktor. Antaranya ialah kekurangan keupayaan penghasilan tisu lemak secara normal pada setiap bahagian badan. Keadaan ini seterusnya membuatkan proses kedutan kulit berlaku. Perihal perubahan ini diceritakan oleh pengarang yang secara tidak langsung berjaya memperlihatkan perbezaan yang wujud selepas mengalami proses penuaan.

\section{Dimensi Psikologi}

Shahnon seterusnya membawa pembaca kepada proses penuaan dalam dimensi psikologi. Perkara ini jelas dapat diteliti melalui keperihalan bapa kepada watak "Aku". Jika dibandingkan dengan dahulu, bapanya kini selalu menghabiskan masa dengan merenung jauh. Hal ini demikian kerana, bapanya sudah tidak mempunyai pekerjaan yang hendak dilakukan kerana sawah padi yang dimilikinya telah dikambus untuk dijadikan kilang. Menurut Saedah (2011, p. 34), golongan tua sering berasa sunyi selepas bersara atau berhenti kerja. Keadaan ini akan menyebabkan emosi dan psikologi mereka turut berubah dan terganggu. Kesunyian itu akhirnya 
akan meresahkan mereka, termasuk menyebabkan mereka kerap merenung ke dalam diri. Dalam karya ini bapa kepada watak utama telah menjadikan lesung hindik sebagai tempat merenung jauh mengenangkan sejarahnya yang banyak ranjau dan duri:

Biasanya kalau lesung hindik tidak digunakan, batangnya sering menjadi tempat kucing tersadai atau ayam bertenggek. Kemudian, emaklah yang sibuk membersihkan lesung itu kembali apabila tahi kucing dan tahi ayam berselerak. Atau tempat bapa merenungi jauh entah ke mana mengenangkan sejarahnya yang banyak ranjau dan tangisan itu.

(Shahnon, 2003, pp. 17-18)

Situasi di atas memperlihatkan psikologi yang wujud dalam kalangan golongan tua.

Di samping merenung jauh, golongan tua juga gemar menceritakan semula apa-apa yang berlaku dalam kehidupan silam mereka. Perubahan yang berlaku secara drastik kepada keadaan sekeliling mereka sukar untuk diterima. Oleh itu, bagi mereka keadaan dan peristiwa lepas adalah lebih baik jika dibandingkan dengan keadaan semasa. Perkara ini turut dapat diamati melalui watak bapa yang sering bercerita kepada menantunya Yati dan cucunya Seha akan pengalaman lampaunya yang berlaku di Kampung Banggul. Pengarang novelet mencatatkannya seperti yang berikut:

Sekarang kita mandi di pancur, kerana pancur sudah lama masuk. Atuk dan nenek yang memberitahu Seha dulu. Dulu memang atuk dan nenek kena pergi mandi sungai juga walaupun kotor kerana pancur belum masuk. Kotor pun kotorlah kerana tak ada lagi tempat lain untuk bermandi manda selepas bersawah dan berbaruh.

(Shahnon, 2003, p. 52)

Kelihatan dalam petikan ini bahawa suasana yang lepas lebih menjadi kegemaran, walaupun keadaan itu jika dinilai mempunyai kekurangan, termasuk sungai yang kotor. Pokoknya, suasana masa lampau dalam kehidupan atuk dan nenek masih dianggap baik dan disukai. Begitulah, menurut pengarang golongan tua seolah-olah hidup dalam alam mimpi sementara menanti hari kematian mengunjung tiba (Shahnon, 2003, p. 85). 
Dalam konteks ini, Saedah (2011, p. 34) menyatakan bahawa perkongsian cerita dengan orang-orang sekelilingnya, terutama anak cucu sendiri, boleh menjadikan seseorang warga emas kembali "segar". Oleh itu, anak cucu tidak wajar merungut sekiranya ibu bapa atau datuk nenek sering mengulangulang cerita yang sama.

Proses penuaan dari sudut psikologi juga dapat dilihat melalui perubahan personaliti yang berlaku kepada golongan tua. Mereka yang dahulunya mempunyai personaliti berkeyakinan tinggi telah berubah kepada personaliti yang lebih sensitif(Chee, 1993, p. 23). Hal ini digambarkan oleh pengarang novelet melalui penampilan watak utama yang lebih berhati-hati dalam berurusan dengan kedua-dua ibu bapanya:

Kini barulah Yati faham setiap langkah dan rancangan yang disusun oleh abang. Abang benar-benar mengambil kesempatan daripada kegemaran Seha itu semata-mata untuk terus menjaga hati emak dan bapa. Memang tak ada kaedah lain lagi bagi menyeronokkan emak dan bapa sekarang selain menyuruh mereka kembali bersawah berbaruh dengan hal-hal yang ada kaitan dengan jelapang, padi, selut, keweh dan hujan serta angin dan sebagainya.

(Shahnon, 2003, p. 73)

Dalam konteks ini watak utama telah bersetuju dengan permintaan Seha yang ingin turun bersawah kerana mahu menjaga hati kedua-dua ibu bapanya. Sebenarnya, pada peringkat umur sebegini golongan tua tidak lagi memerlukan wang ringgit, mahupun sesuatu yang boleh dibanggakan. Sebaliknya, mereka memerlukan belaian kasih sayang daripada anak cucu. Malah, pada peringkat ini mereka mudah sensitif, dan ada ketikanya sikap mereka seperti kembali kembali ke zaman kanak-kanak. Maka, anak cucu perlu bertolak ansur dan banyak bersabar bagi menenangkan keadaan. Dalam novelet ini watak utama telah memahami keadaan ini dan bersetuju dengan kehendak Seha untuk turun ke sawah bagi mengambil hati orang tuanya.

\section{Dimensi Sosial}

Melalui noveletnya "Sebuah Mimpi buat Hari Tua" Shahnon turut membawa pembaca untuk mendalami proses penuaan dalam dimensi sosial. Dalam cerita ini pengarang telah menyampaikan bahawa kedua-dua ibu bapa watak utama amat selesa dengan keadaan di Kampung Banggul. Walaupun 
sudah beberapa kali diajak untuk tinggal bersama di Kuala Lumpur, mereka masih bertegas mahu kekal di kampung (Shahnon, 2003, p. 63). Menurut gerontologi kritikal, pada kebiasaannya warga tua lebih senang dengan persekitaran yang telah menjadi sebati dengan diri mereka. Misalnya, rumah, keluarga, saudara-mara dan rakan taulan yang telah lama mereka kenali dan dampingi. Perubahan keadaan yang drastik sememangnya sukar untuk diterima oleh warga tua, terutamanya jika mereka telah biasa dengan sesuatu persekitaran atau suasana terlalu lama. Situasi ini wujud kerana kawasan persekitaran telah memberikan impak kepada mereka. Menurut Hooyman dan Kiyak (2008, p. 87):

The environment plays a more dominant role for older people with ADL limitations because their capacity to control their surroundings, such as leaving an undesirable setting, is considerably reduced.

Perubahan persekitaran sememangnya mengehadkan kebolehan mereka untuk mengawal keadaan sekeliling. Oleh itu, dapat difahami sebab ibu bapa watak utama tidak mahu berpindah ke Kuala Lumpur. Hal ini demikian kerana, keadaan di Kuala Lumpur sama sekali tidak sama dengan keadaan di Kampung Banggul yang memberikan kapasiti pengawalan sepenuhnya terhadap keadaan sekeliling. Jika di Kampung Banggul, mereka boleh bersawah, menangkap ikan, burung dan sebagainya, tetapi di Kuala Lumpur kesemua ini tidak wujud. Malah, mereka memerlukan proses adaptasi yang pastinya sukar. Sesuai dengan sifatnya sebagai bahan gerontologi sastera, semua ini disampaikan dalam "Sebuah Mimpi buat Hari Tua" melalui pendirian ibu bapa watak yang tidak mahu berpindah ke Kuala Lumpur.

Dimensi sosial seterusnya dapat dianalisis melalui perubahan peranan warga tua dalam masyarakat. Jika dahulu mereka menjadi penyumbang utama kepada masyarakat, namun setelah mencecah usia tua, keadaan sebaliknya berlaku. Perkara ini ditampilkan oleh pengarang melalui perlakuan watak Pak Cik Leman. Pada satu ketika Pak Cik Leman berkata:

\footnotetext{
"Siapa yang nak ambil Pak Cik Leman kerja kilang. Orang ambil anak-anak dara saja, janda-janda muda saja, ceredung-ceredung dan anak-anak muda saja. Macam Pak Leman ni, siapa yang nak ambil. Sepak tunggul boleh".
}

(Shahnon, 2003, p. 70) 
Keadaan yang sama turut dialami oleh kedua-dua ibu bapa watak utama, dan hal ini telah diperakui olehnya:

Apa boleh bapa dan emak buat sekarang? Dari kecil sampai tua, yang bapa tahu hanya turun sawah, naik sawah, turun sawah, naik sawah. Yang lain bapa dan mak tak boleh buat. Kalau hendak bawa emak dan bapa ke Kuala Lumpur pun, bapa dan emak tak boleh berbuat apa-apa juga.

(Shahnon, 2003, p. 87)

Secara amnya, situasi seperti ini wujud kerana perubahan teknologi dan cara hidup yang begitu pantas sehingga tidak dapat diikuti oleh warga tua. Dalam hal ini Hooyman dan Kiyak (2008, p. 87) dalam kajian mereka menegaskan bahawa:

... we have tended to undervalue older people and to assume that most of them are less intelligent than younger people; that they are unemployable, non-productive, uninterested in interacting with younger people, forgetful and asexual. As a result, they have been limited in their access to activities such as jobs in high-tech fields.

Begitulah, warga tua dianggap tidak lagi mempunyai akal fikiran yang baik seperti orang muda dan membawa kepada perubahan peranan sosial mereka dalam masyarakat. Mereka terus disisihkan dengan anggapan bahawa mereka sudah tidak dapat lagi berfungsi atau membantu meningkatkan produktiviti.

Seterusnya, perubahan dalam peranan sosial warga tua turut dapat dibincangkan melalui hubungan yang wujud dengan orang sekeliling. Dalam gerontologi klinikal, menurut Cherlin dan Furstenberg $(1985$, p. 97) terdapat tiga corak perhubungan antara datuk dan nenek dengan cucu mereka, iaitu:

(1) Grandparents may be detached and have little contact with the grandchildren, especially when it involves geographical distance.

(2) The relationship could be passive because although there is regular contact it is somewhat superficial.

(3) The relationship is active and the grandparents are involved in the lives of the grandchildren. 
Dalam novelet "Sebuah Mimpi Buat Hari Tua" hubungan datuk dan nenek bersama-sama cucu mereka Seha termasuk jenis yang ketiga, iaitu aktif. Mereka terlibat secara terus dalam kehidupan Seha. Watak utama tidak pernah cuba memutuskan hubungan yang wujud. Malah, beliau kadangkala membawa Seha pulang ke kampung untuk berjumpa dengan datuk dan neneknya. Seha begitu dimanjakan oleh datuk dan neneknya. Kesemua kerenah Seha pasti dilayani tanpa sebarang rungutan (Shahnon, 2003, pp. 16-17). Malah, permintaan Seha untuk turun ke sawah bersama-sama datuk dan nenek turut diterima, walaupun Seha masih kecil dan tidak mampu untuk bersawah seperti orang dewasa. Pengarang novelet mencatatkan perkara ini seperti yang berikut:

Apabila Seha sudah biasa, biar Seha seorang sajalah yang bersawahan. Kita semua tengok dari atas tebing paya. Seha cucu atuk yang atuk paling sayang sekali. Atuk tak ada cucu lain macam Seha. Seha suka bersawahan macam atuk dan nenak juga. Tak mengapa. Terpulanglah pada Seha.

(Shahnon, 2003, p. 91):

Terdapat beberapa sebab mengapa datuk dan nenek Seha tidak menghalang permintaannya untuk turun ke sawah. Antaranya mereka memang gemar meluangkan masa untuk bersama-sama Seha dan menyediakan tempat selamat ketika cucu itu berjauhan daripada ibu bapanya. Pada masa yang sama, mereka juga ingin menurunkan semangat jati diri dan tradisi keluarga mereka kepada Seha. Dalam hal ini, menurut gerontologi klinikal, Brussoni dan Boon (1998, p. 267) mencatatkan:

In many instances the relationships that exist between grandparents and their grandchildren can be said to benefit both parties. In general grandparents provide a safe place for children to practice being away from their parents. They provide a sense of identity and family history and traditions. They are also known to make time to play and participate in various types of activities with the grandchildren.

Begitulah, dalam novelet "Sebuah Mimpi Buat Hari Tua" wujud hubungan aktif antara Seha dengan datuk dan neneknya. Mereka bertiga sering meluangkan masa bersama. 
Sebenarnya, selain daripada mendapat perhatian serta belaian kasih datuk dan neneknya, Seha sendiri telah memberikan dampak kepada kehidupan mereka berdua. Misalnya, datuk dan neneknya akhirnya mengambil keputusan yang begitu drastik yang selama ini pasti tidak dipersetujui atau didiamkan sahaja, iaitu untuk berpindah ke Kuala Lumpur. Datuk dan neneknya akhirnya bersetuju untuk pindah ke Kuala Lumpur setelah Seha tidak berhenti-henti merayu (Shahnon, 2003, pp. 100-108). Dalam gerontologi klinikal, menurut Hooyman dan Kiyak (2008, p. 88), terdapat beberapa sebab yang membolehkan keadaan ini berlaku, iaitu:

... grandparents generally derive great emotional satisfaction from interacting with their grandchildren and from opportunities to observe grandchildren's development and share their activities. They want to have an influence on their grandchildren, typically to encourage high moral standards, integrity, a commitment to succeed, and religious beliefs and values.

Begitulah juga dalam novelet "Sebuah Mimpi Buat Hari Tua", sebagai suatu sumber gerontologi sastera, dapat diperhatikan bahawa datuk dan nenek Seha mahu melihat dia membesar di sisi mereka. Pada masa yang sama, mereka juga ingin menerapkan nilai-nilai yang murni kepadanya. Keputusan untuk berpindah ke Kuala Lumpur adalah untuk kebaikan bersama. Dalam erti kata lain. Seha adalah segala-galanya bagi mereka dan mereka amat sayang kepadanya.

\section{KESIMPULAN}

Secara kesimpulannya, tidak dapat dinafikan bahawa usia memberikan pengaruh dalam proses penulisan pengarang. Dalam menghasilkan korpus karyanya Shahnon memperlihatkan perubahan yang amat ketara. Pada usia muda beliau lebih lantang dalam membawa isu semasa dalam karyanya. Namun begitu, apabila memasuki usia emas, karya yang dihasilkan kelihatan lebih tenang. Fokusnya lebih pada kisah warga tua menjalani sisa kehidupan mereka. Novelet "Sebuah Mimpu Buat Hari Tua" yang dihasilkannya pada usia sekitar usia 70 tahun ialah contoh terbaik dalam memperlihatkan perkara ini.

Melalui analisis yang dilaksanakan, jelas bahawa sesuai dengan umurnya sendiri Shahnon telah membawa pembaca menelusuri proses penuaan dalam pelbagai dimensi, antaranya termasuklah biologi, psikologi dan 
sosial. Ketiga-tiganya saling berkaitan dan memainkan peranan dalam memperlihatkan bagaimana warga tua meniti kehidupan di penghujung hayat mereka. Sebagai suatu sumber gerontologi sastera, novelet "Sebuah Mimpi Buat Hari Tua" telah memperlihatkan liku-liku perubahan yang berlaku dalam ketiga-ketiga dimensi tersebut melalui naratif yang menarik. Umumnya, apa-apa yang dipaparkan oleh Shahnon kelihatan selari dengan pandangan para sarjana dalam gerontologi kritikal.

\section{RUJUKAN}

Brussoni, M.J \& Boon, S.D. (1998). "Grandparental impact in young adults' relationship with their closet grandparents: The role of relationship strength and emotional closeness. International Journal of Aging and Human Development, 45, 267-286.

Chee Yee Tang. (1993). Psikologi perkembangan. Kuala Lumpur: Kumpulan Budiman.

Cherlin, A. \& Furstenberg, F.F. Jr. (1985). Styles and strategies of grandpareting. Beverly Hills: Sage.

Hooyman, Nancy R. \& H. Asuman Kiyak. (2008). Social gerontology: A multidisciplinary perspective. New York: Pearson.

Kart, Cary S. \& Kinney, Jennifer M. (2001) The realities of aging: An introduction to gerontology. New Yok: Pearson.

Rahimah A. Hamid. (2017). Proses kreatif sensitiviti dan kreativiti pengarang. Kuala Lumpur: Dewan Bahasa dan Pustaka.

Saedah A. Ghani. (2011). “Anak, cucu peneman di usia tua”. Utusan, 30 Disember, 34.

Shahnon Ahmad. (2003). Lamunan puitis - sebuah trilogi. Kuala Lumpur: Dewan Bahasa dan Pustaka.

Shahnon Ahmad. (2003). "Sebuah Mimpi Buat Hari Tua" in Lamunan Puitis Sebuah Trilogi. Kuala Lumpur: Dewan Bahasa dan Pustaka, 3-108.

Sugeng Sugiyono. (1993). "Memahami Tabiat dan Karakteristik Sastra dalam Islam" dalam Bunga Rampai Bahasa Sastera dan Kebudayaan Islam. Disunting oleh Sugeng Sugiyono. Yogjakarta: Fakultas Adab IAIN Sunan Kalijaga.

Zeilig, Hannah. (2011). "The critical use of narrative and literature in gerontology", International Journal of Ageing and Later Life, 6 (2), 7-37.

Received: 9 March 2018

Accepted: 1 Jun 2018 